\title{
Renal Pelvis Papillary Urothelial
}

\section{Carcinoma}

National Cancer Institute

\section{Source}

National Cancer Institute. Renal Pelvis Papillary Urothelial Carcinoma. NCI Thesaurus.

Code C6148.

A papillary transitional cell carcinoma that arises from the renal pelvis. 